\title{
Level of Awareness about Climate Change among the Pastoral Community
}

\author{
Janet C. Korir \\ Department of Geography, Moi University, Kenya
}

Copyright $\subseteq 2019$ by authors, all rights reserved. Authors agree that this article remains permanently open access under the terms of the Creative Commons Attribution License 4.0 International License

\begin{abstract}
The recognition by the government of Kenya of the adverse effects caused by climate change prompted the Ministry of Environment and Mineral Resources collaborating with other stakeholders to develop the National Climate Change Response Strategy (NCCRS) in 2010 in preparation for the adversity. However, the aim of attaining Kenya's Vision 2030 has remained a problem in implementation especially due to the lack of awareness by the local communities. This has resulted to food deficit and

enhance resilience of pastoral communities to impacts of climate change, effective and appropriate dissemination of climate information at the local level and those that provide access to socio-economic institutions such as capital, water and information should be formulated and implemented. The study findings are aimed at benefiting the local community through creating awareness on the adoption of new livelihood technologies proposed in the study hence improving their resilience to climate change.
\end{abstract} nutritional challenges that have deepened the poverty levels of most rural and urban households. This is evident in Narok County where frequent droughts and floods have threatened the pastoral livelihoods in the recent past. Climate change awareness is critical in ensuring successful response and adaptation at local level in developing countries. This paper is a result of a study that sought to assess the level of awareness of the pastoral community on the causes and impact of climate change (ICC) in Narok County. The findings of the study were based on a detailed survey conducted through face-face interviews from a sample of 415 households that was determined through multistage cluster sampling and simple random sampling techniques. An analysis of the collected data indicated that pastoralists have observed changes in climate change related indicators such as temperature, vegetation cover, and rainfall over the past two decades from their locally acquired knowledge. While the majority $(84.1 \%)$ of the respondents indicated awareness of climate change causes and impacts, and the overdependence on their locally available knowledge $(88.2 \%)$ portrayed that most $(37 \%)$ had a belief that climate change was a punishment from the gods and ancestral spirits for man's offences. On the contrary, only $(2.2 \%)$ and $(23.4 \%)$ attributed climate change to greenhouse gases and deforestation respectively, scientifically proven causes upon which mitigation could be drawn. The belief misguides and could explain why the pastoral communities are still hit hard by the effects of climate change. The level of awareness was significantly different across respondent categories (Pearson Chi Square of 19.139 and p-value of 0.001) and regions (Pearson Chi Square of 30.396 and p-value of 0.000 ). Therefore, to
Keywords Pastoral Community, Climate Change, Rainfall, Temperature, Kenya

\section{Introduction}

Climate change is a global issue that poses enormous challenges described as the leading threat of our time by the Inter-governmental Panel on Climate Change [1].The report indicates that there were frequent and intense climates to the extreme which had been observed in the recent past and for which global warming was said to have reached $0.5^{\circ} \mathrm{C}[1, \mathrm{p} .6]$. According to Buchdahl [2], both the earth's surface and lowest part of the atmosphere have warmed up on an average of about $0.6^{\circ} \mathrm{c}$ during the last 100 years. This increase in global average surface temperature is now considered to be most probable due to the increases in greenhouse gas (GHG) emissions and concurrent increases in atmospheric greenhouse gas concentrations [1].This rapid increase has pushed many people to believe that a paradigm shift in values and social-economic relations is needed to address the root cause of climate change. As a result, a growing awareness through the involvement of the local action has been witnessed globally as a means towards responding to climate change [3].

The African continent risks becoming a major global food crisis epicenter if climate change issues remain unaddressed at local levels [4]. In Africa, the major economic sectors are vulnerable to current climate change which is exacerbated by obstacles such as high level of 
poverty, ecosystem degradation and complex disasters. Some of the worst effects of climate change on human health and agriculture will be in sub- Saharan Africa, where the crop yield is expected to decline by $10-20 \%$ by 2050 if not checked [5]. This will adversely contribute to poor living conditions to most of the rural communities.

Narok County with poverty rates of $50 \%$ and about $70 \%$ of its population being pastoralists who derive their livelihood mainly from livestock keeping is facing increasing pressures from climate change, decreased pasture both in quality and quantity, and increasing population [6]. Climate change related shocks such as droughts and floods are becoming more frequent, more severe, and very uncertain in Narok County [7]. FAO [8] reveals a cyclic recurrence of droughts within the county, with major events experienced in 1983-84, 1991, 1993-94, 1999-2000 and 2003 periods. According to IPCC [1], the impacts of climate change on vegetation dependent livelihoods cover a wide range of possibilities including impact on health and welfare, loss of income, reduction in availability of food and loss of cultural habitat. This was evident from 1999-2000, and in 2009 when the then Narok District, lost over 500,000 animals due to prolonged drought, a situation that led to acute food shortages and rise in incidences of human-wildlife conflicts $[6,9,10,11]$. It is upon this backdrop that in this paper, the author addresses the level of awareness of the pastoral community in Narok County on the impact and causes of climate change so as to create a source of knowledge for the community to be prepared in case of such occurrences and take precautionary measures where necessary.

\section{Literature Underpinning}

The emmission of green house gases (GHGs) leading to climate change has often been blamed on the natural variability and human interactions.This is bacause the increased levels of greenhouse gases has caused increased levels of global temperatures and subsequentclimate change [12]. While the global average surface temperatures have shown an increasethrough the $20^{\text {th }}$ century by about $0.6^{\circ} \mathrm{C}$, this was still expected to increase in the $21^{\mathrm{st}}$ century faster than any that has occurred in the past 10000 years [13].

The Special Assessment Report of the Inter-governmental Panel on Climate Change [1] emphasized that global warming is mostly due to man-made emissions of greenhouse gases from human activities. There is consensus among many scientists that the anthropogenic cause of increment of GHGs in the atmosphere is the main cause of the climate change incidences experienced. These according to Kamal [14], are mainly caused by land use changes such as deforestation particularly from developing countries, and the burning of fossil fuels specifically developing countries.

Ogallo [15] pinpoints the prevailing low level of awareness among most communities in Kenya about climate change issues, the existence of the United Nation Framework Convention on Climate Change (UNFCCC), and about the opportunities it provides for mitigation and adaptation to climate change. Similarly, a survey undertaken during the development of National Climate Change Response Strategy (NCCRS) in 2010 confirmed that public awareness about climate change in Kenya is still very low. National Climate Change Action Plan (NCCAP) corroborates this position further by stating that even though significant climate change knowledge is currently generated by Kenyan institutions and individuals including government, research and academic institutions, civil society organizations (CSOs) and private sector companies, there is still limited sharing of climate change information and knowledge. Its access and use have been inhibited by factors such as language barrier, unsuitable mode of communication, poor infrastructure, and poor repackaging of the information [16].

This low level of awareness is even worse in the Arid and Semi-Arid Lands (ASALs) of Kenya. In the published 'report on access and use of climate change information in the ASALs of Kenya, KCCWG [16] noted that although majority of the people across the counties were aware of the fact that something is happening to their climate, they did not rightly associate it with the concept and phenomenon of climate change; and that though they were able to identify the impacts of climate change, they lacked access to information that could assist them to beware of the climate change.

However, most farmers are aware of changes that are happening in climate parameters and that are affecting their farming, but they may not understand why there are changes. According to Debela [17], a significant proportion of Boran smallholders believe that humanity is cursed and supernatural forces are the primary cause of climate change. None of them mentioned the role of greenhouse gases in driving climate change. Yet according to Deressa [18], despite having perceived changes in temperature and rainfall, a large percentage of farmers in Nile Basin did not make any adjustments to their farming. The scenario was different from two similar studies in Ghana by Ndamani and Watanabe [19] and Kusakari [20] where farmers had perceived that the frequency and severity of floods had decreased more than drought due to decreasing rainfall trend and they were able to adjust. They noted that in the past, the rains used to begin in March, while of late, they began to arrive as late as June and even July hence had also started to adjust their farming activities.

According to Omondi [21], social capital had a role to play in the understanding of the climate change phenomenon amongst the people of the Mara River Basin. They therefore did not report climate change in terms of 
mean temperatures or precipitation or statistical figures but highlighted mostly the inter-annual changes or events that were of importance to them as a community and those they could observe or experience. However for smallholders in Borana pastoral system in Moyale the experience of extreme events informed them about changing climate from 1992-2012, although there was limited meteorological evidence and in this regard played crucial role in influencing participants' attitude [17].

Additionally, the knowledge and perceptions of communities and the farmers about climate variability and change according to Egbe [22], influence the way they respond to mitigation and adaptation initiatives and climate policies. Furthermore, Deressa [18] agrees that a better understanding of farmers' perceptions of climate change, ongoing adaptation measures, and the decision-making process is important to inform policies aimed at promoting successful adaptation strategies for the agricultural sector.

Farmers with better knowledge and information on climate change and agronomic practices are able to use adaptation strategies to cope with change in climate and other socio-economic conditions [23]. A better understanding of the local dimensions of climatic change is also essential to develop appropriate adaptation measures that can mitigate the adverse impact of climate change. Therefore, awareness of the potential benefits from adaptation is an important issue. Yesuf [24] singled out two main barriers to climate change adaptation by farmers in the Nile Basin as lack of information on adaptation methods and financial constraints. They therefore noted that frequent access to more accurate climate related information from meteorological centres, as well as from formal and informal institutions had a positive correlation with the adoption of climate change adaptation strategies.

Since climate change is a serious challenge requiring active participation of all members of the society, the most up to date techniques for creating public awareness amongst all segments of the populace are recommended by NCCAP which include the use of radio, mobile phones, television, internet, newspapers, group meetings and 'barazas', social media, opinion leaders, drama, songs, and skits [25]. However, the question to answer is: which of these have successfully been used so far among residents of Kenyan ASALs and with what effect.

\section{Methodology}

The study employed use of descriptive survey research design, which enabled presentation of variables under investigation depicting the level of awareness among the pastoral community of Narok County (see appendix). The design was deemed appropriate in exploring the knowledge ability [26] of the respondents on the causes and impact of climate change in the County. The target population constituted pastoralists' households in the County who were purposively selected from Narok East $(82,956)$, Narok South $(181,905)$ and Narok West $(135,939)$ sub-counties since the 3 sub-counties are the pastoral hotspots of the County [27].Using multi-stage cluster sampling to select the study locations, Krejcie sampling formula [28] was used to compute the sample of households from the 79,971 households that constitute pastoralists in the County [27].

The formula is presented as follows:

$$
n=\frac{\left(X^{2} N p q\right)}{\left(\left(d^{2}(N-1)+\left(X^{2} p q\right)\right)\right)} \text {. }
$$

Where $n$ is the desired sample size; $\mathrm{N}$ is the target population; $p$ is the population proportion $(0.5) ; \mathrm{d}$ is the degree of accuracy reflected by the amount of error that can be tolerated in fluctuation of a size about a population and corresponds to the significance level with a standard error of the proportion at the corresponding confidence level (95\%); $\chi^{2}$ is the table chi square value for one degree of freedom relative to the desired level of confidence ( $\chi^{2}$ $=3.841$ at $95 \%$ confidence level); and $q$ is $1-p$. The sample served as adequate representation of the population which was studied. Using this formula, a total of 382 households was then arrived at as the sample of the study.

Besides this number of households, an additional 33 households (8.6\% of sample), 8 in Narok East, 14 in Narok South and 11 in Narok West, proportionately) was sampled to reduce sampling error, rendering sampling approach representative of the general population and take care of any non-meaningful questionnaires collected [29]. Therefore a total of 415 pastoral households were considered for the study.

Data collection was done through questionnaire, interview sand observation. A pilot study that involved 40 pastoralists not included in the study sample was conducted to ascertain the reliability and validity of the instruments.

The descriptive data that was collected was analysed using descriptive statistical tools of analysis. Its presentation was done in form of frequencies, percentages and means to test the level of awareness about cause and impacts of climate change by pastoralists in Narok County. Besides, chi- square test was also done to test the significant difference on cross-tabulated categorical dependent variables. The data was then presented using tables.

\section{Results and Discussion}

\subsection{Topography of Narok County}

Conducted in the pastoral community of Narok County, in the Southern part of the Great Rift Valley, this study sought to find out the level of awareness of the community on the causes and impacts of climate change. The County has two types of topography; the highland towards the 
forest in the west that rises up an altitude of 3,100 meters above the sea level and the lowland, which extends up to the boundary with Tanzania in the South with an altitude of 460 meters above sea level. The highlands favour intensive agricultural production because of rich volcanic soils while the lowland area is inhabited by the nomadic pastoralists since the soils are poor and the rains are unreliable. The soils are however diverse, ranging from mountain soils to those on the plains and seasonal swamps. A substantial part of the county is covered by fairly shallow soils which if not properly managed can be easily eroded [6].

While the temperatures in the county range from a minimum of $8^{0} \mathrm{C}$ to a maximum of $28^{\circ} \mathrm{C}$, it experiences two rainy seasons with short rains averaging $500 \mathrm{mmwhile}$ long rains averaging $1,800 \mathrm{~mm}$ per annum. Floods are experienced in some low lying parts of the county especially during the heavy rainy seasons, consequent of which dams have been created by some farmers to prevent soil erosion and conserve some of the run off for agricultural purposes.

The county has abundant natural forest most of which is in the Mau complex but there are no forest-based industries to generate employment and foreign exchange. The forest is mainly used to generate firewood, fruits, fodder for animals and other products for local consumption. However, due to the high temperatures experienced in the county, most of the plant species are acacia and other scrubs depicting shallow and less fertile soils [6].

Narok County grapples with the challenges of water shortages since the area is prone to long periodic droughts for the better part of the year. Most rivers also dry up during the dry season. Hence access to surface water for domestic and livestock consumption continues to be a problem. The main rivers found in Narok County are Mara and Ewaso Ngiro with very poor ground water potentiality.

\subsection{Pastoralist Level of Awareness}

This paper aimed to show an assessment of the level of awareness among pastoralists in Narok County on the main causes and impacts of climate change in the County. From the responses illustrated in Table 1, it is apparent that majority of the respondents $(84.1 \%)$ in the study area were aware of the main causes and impacts of climate change. When asked of the main source of information on causes and impacts of climate change in the area, majority (88.2\%) of them indicated that they just observed by their own, while $8 \%$ were of the opinion that they got the information from their local area chiefs and $2.1 \%$ from school. A point to note in these responses is the fact that livestock officers do not seem to be disseminating enough information (only $1.4 \%)$ to the pastoralists on matters climate change although the phenomenon is bound to affect their animals.

When the household respondents were asked to give the possible cause of climate change, a significant proportion (37\%) consider that man has offended the gods and ancestral spirits and that they are under a punishment through calamities of climate change. This was followed by human causes like deforestation and negligence of peace $(23.4 \%)$ with majority from Narok West. Biblical explanation which included the expected events of the last days was mentioned by $15.4 \%$ of the respondents and yet $9.6 \%$ alluded that they did not know what caused the change in climate. A point to note is that a very small portion $(2.2 \%)$ of the respondents attributed climate change to greenhouse gases.

Table 1. Level of awareness to impacts of climate change and sources of information across the Pastoralist regions

\begin{tabular}{|c|c|c|c|c|c|}
\hline \multirow{2}{*}{ Indicators/Variables } & \multirow{2}{*}{ No. of Households } & \multicolumn{4}{|c|}{ Sub-Counties } \\
\hline & & Narok West & Narok East & Narok South & Chi $^{2}$ (P-Value) \\
\hline & & (\%) & (\%) & (\%) & \\
\hline Yes & 349 & 42.7 & 18.0 & 39.3 & \multirow{2}{*}{$8.517(\mathbf{0 . 0 1 4}) * *$} \\
\hline No & 66 & 59.0 & 6.1 & 34.9 & \\
\hline $\mathbf{n}$ & 415 & 188 & 67 & 160 & \\
\hline Sources of information & & $(\%)$ & $(\%)$ & $(\%)$ & \\
\hline Own observation & 366 & 45.6 & 17.2 & 37.2 & \\
\hline Livestock officer & 6 & 34.5 & 33.5 & 32.0 & \\
\hline NGOs & 2 & 0.0 & 0.0 & 100.0 & \multirow{3}{*}{$11.930(0.290)$} \\
\hline MCAs & 1 & 0.0 & 0.0 & 100.0 & \\
\hline Local area chief & 33 & 45.6 & 3.0 & 51.4 & \\
\hline School & 7 & 56.4 & 14.4 & 29.2 & \\
\hline $\mathbf{n}$ & 415 & 188 & 67 & 160 & \\
\hline
\end{tabular}

\footnotetext{
$* *(p<0.05)$
} 
Table 2. The households' responses on causes of climate change

\begin{tabular}{|c|c|c|c|c|c|}
\hline Causes of climate change & Frequency & $\%$ & Narok West & Narok East & Narok South \\
\hline & & & $\%$ & $\%$ & $\%$ \\
\hline Punishment from gods and ancestors & 153 & 37 & 45 & 12.3 & 42.7 \\
\hline Human causes & 97 & 23.4 & 60.2 & 15.2 & 34.6 \\
\hline Biblical explanations & 64 & 15.4 & 37 & 45,2 & 28.8 \\
\hline Greenhouse gases & 9 & 2.2 & 17.3 & 31 & 51.7 \\
\hline Natural causes & 52 & 12.5 & 39.5 & 20.3 & 40.2 \\
\hline Don't know & 40 & 9.6 & 11.5 & 42 & 47.3 \\
\hline $\mathrm{n}$ & 415 & 100 & 188 & 67 & 160 \\
\hline
\end{tabular}

Table 3. Significant climatic changes and the level of awareness across the three sub-counties

\begin{tabular}{|c|c|c|c|c|c|c|c|c|c|}
\hline & & \multicolumn{3}{|c|}{ Awareness } & & \multicolumn{4}{|c|}{ Sub-Counties } \\
\hline Variables & $\mathbf{n}$ & $\begin{array}{l}\text { Yes } \\
(\%) \\
\end{array}$ & $\begin{array}{l}\text { No } \\
(\%) \\
\end{array}$ & Chi2(P-Value) & $\mathbf{N}$ & $\begin{array}{c}\text { Narok } \\
\text { West }\end{array}$ & $\begin{array}{c}\text { Narok } \\
\text { East }\end{array}$ & $\begin{array}{l}\text { Narok } \\
\text { South } \\
\end{array}$ & $\mathrm{Chi}^{2}$ (P-Value) \\
\hline Significant Changes & & & & & & $(\%)$ & $(\%)$ & $(\%)$ & \\
\hline Don't Know & 6 & 34.9 & 65.1 & & 6 & 84.6 & 0.0 & 15.4 & \\
\hline Unpredictable rains & 48 & 93.8 & 6.2 & & 48 & 35.3 & 6.3 & 58.4 & \\
\hline Prolonged drought & 90 & 85.7 & 14.3 & \multirow{3}{*}{$\begin{array}{c}19.139 \\
(\mathbf{0 . 0 0 1}) * * *\end{array}$} & 90 & 49.7 & 0.3 & 50.0 & $\begin{array}{c}30.396 \\
(\mathbf{0 . 0 0 0 ) * * *}\end{array}$ \\
\hline Very hot seasons & 18 & 65.9 & 34.1 & & 18 & 28.2 & 22.3 & 49.5 & \\
\hline $\begin{array}{c}\text { Unpredictable rains, } \\
\text { prolonged draught, and very } \\
\text { hot seasons }\end{array}$ & 253 & 84.1 & 15.9 & & 253 & 48.6 & 20.9 & 30.5 & \\
\hline $\mathbf{n}$ & 415 & 349 & 66 & & 415 & 188 & 67 & 160 & \\
\hline
\end{tabular}

$* * *(\mathrm{p}<0.01)$

In order to further buttress on the respondents' understanding of climate change, they were asked to indicate specific changes regarding rainfall, drought and temperatures. The results (Table 3) show that $61 \%$ of the respondents have witnessed unpredictable rains, prolonged droughts and hot seasons, which they understood to mean climate change. These changes also were significantly different across the two categories of respondents (Pearson Chi Square of 19.139 and p-value of 0.001 ) as well as the three regions of the study area (Pearson Chi Square of 30.396 and p-value of 0.000). This implies that the pastoralists had different perceptions about changes in climate.

As concerns the level of awareness on the climatic change causes and impacts, the findings of the study indicated that majority $(84.1 \%)$ of the respondents from the study area were aware of the main changes and impacts of the climate change. Of those that were aware, majority $(88.2 \%)$ reported to have observed the changes by their own, while $8 \%$ got the information from their local area chief and $2.1 \%$ from school.

It is notable that very few respondents $(2.2 \%)$ mentioned the cause of GHGs while majority (37\%) attributed this to the punishment from gods and ancestors because of man's offenses and failure to respect their supernatural beings. Human interference with nature through deforestation and disturbance of peace in the environment was also considered a cause to climate change. The Maasai pastoral community holds with a high regards their relationship with their gods ('engai'), ancestors and their local environment.

The results imply that, although the pastoralists have noticed changes in climate over time, they are however unaware of the actual causes of climate change, possibly because of lack or limited access to weather and climate related information. This was reinforced by the report from one of the focus group discussants (FGDs) at Siana, who indicated that pastoralists do not get access of information from the weather stations and that the pastoralists due to lack of information, they have defined their own ways of telling changes in climate which include changes in star arrangements, disappearance of termites and some birds like hornbill (ormuntut) and ravens (orkurik) and the failure of some animals to make noise that used to be a sign of coming rains. The report agrees with the earlier sentiments by Debela [17] who noted that pastoral systems of Borana had no idea of the influence of GHGs on climate but majority had perceived this to be caused by supernatural forces and natural processes. The sentiments also corroborates with the findings of Ogallo [15] and NCCRS (2012) who also affirmed that there is low level of awareness about climate change issues amongst most communities in Kenya although significant climate change knowledge is currently being generated by Kenyan institutions. There is therefore an urgent need to educate both the pastoralists and small scale farmers on both the causes and impacts of climate change before encouraging them to adapt to it because climate change is real. 
Table 4. Respondents' access to basic information by coping and sub-counties

\begin{tabular}{|c|c|c|c|c|c|c|c|c|}
\hline \multirow[b]{2}{*}{ Variables } & \multirow{2}{*}{$\begin{array}{c}\text { No. of } \\
\text { Households }\end{array}$} & \multicolumn{3}{|c|}{ Coping with ICC } & \multicolumn{4}{|c|}{ Sub-Counties } \\
\hline & & $\begin{array}{l}\text { Yes } \\
(\%)\end{array}$ & $\begin{array}{l}\text { No } \\
(\%)\end{array}$ & $\mathrm{Chi}^{2}$ (P-Value) & $\begin{array}{c}\text { Narok } \\
\text { West }\end{array}$ & $\begin{array}{c}\text { Narok } \\
\text { East }\end{array}$ & $\begin{array}{l}\text { Narok } \\
\text { South }\end{array}$ & $\mathrm{Chi}^{2}$ (P-Value) \\
\hline \multicolumn{9}{|c|}{ Information Access } \\
\hline Yes & 118 & 30.8 & 24.3 & \multirow{2}{*}{$1.973(0.160)$} & 28.0 & 28.8 & 43.2 & \multirow{2}{*}{$\begin{array}{c}28.261 \\
(0.000)^{* * *}\end{array}$} \\
\hline No & 297 & 69.2 & 75.7 & & 52.2 & 11.1 & 36.7 & \\
\hline $\mathrm{n}$ & 415 & 263 & 152 & & 188 & 67 & 160 & \\
\hline
\end{tabular}

$* * *(\mathrm{p}<0.01)$

Source: Survey Data 2017

Information access in the study area especially that could help understand climate change better and perhaps adopt appropriate adaptation strategies was limited. This is evident from the results (Table 4 ) which indicated that $71.6 \%$ had no access to necessary information with only $30.8 \%$ of those who accessed information managing to effectively and efficiently cope with ICC. The small number (28.8\%) who indicated to have received information got it either from the local area chief or from their cell phones. The results further revealed that the information access across the three regions of the study area varied statistically and significantly as per the Pearson Chi square of 28.261 and a p-value of 0.000 .

Pastoral community's access to climate data at regular basis as well as improvement in the level of climate change awareness help keep them abreast of climatic changes and thus better their adaptation outcomes. According to Oxley [30], increased sense of awareness and access of information about disaster risk reduction in Pakistan has helped to increase preparedness against floods and drought through developing and forecasting early warning and evacuation systems.

However, lack of access to this information from the relevant authorities did not however bar the pastoralists from describing the specific changes in climate parameters. This is because the results further indicated that significant climatic changes had been observed with regards to rainfall, drought and temperatures with majority of the respondents reporting prolonged drought, unpredictable rains and hot seasons. This response on the indicators of climate change confirmed the awareness of the pastoralists of the changing climate. Hence this result implies that though the pastoral community had limited access to information on climate change they were still in a position to design their own ways of telling and describing the changes. Response from one of the key informant indicated use of indigenous ways of telling changes in climate which include changes in star arrangements, disappearance of termites and some birds like hornbill (ormuntut) and ravens (orkurik) and the failure of some animals to make noise that used to be a sign of coming rains. This is in line with the report by Omondi [21] who noted that the locals do not report climate change in terms of mean temperatures or precipitation because their report of knowledge on climate change is not based on statistical figures but rather on things they can observe or experience.

Furthermore, their observed views corroborates with the report by the meteorological department that indicate decrease in rainfall amounts and increased annual temperatures since 1950. The climate change related indicators have been associated with unpredictable rains, prolonged droughts, and very hot seasons in the study area. This was indicated by meteorological report (2017) which showed that rainfall has continuously declined from an annual average of $800 \mathrm{~mm}$ in 1980 to an annual average of $750 \mathrm{~mm}$ in 2016. (Figure1)

Temperature trends have also been on the rise from an annual minimum average of $8^{\circ} \mathrm{C}$ in 1980 to an annual minimum average of $12^{\circ} \mathrm{C}$ in 2016 (Figure 2). Similar findings have also been documented by Manyatsi [31] who reiterated that changes in precipitation patterns, rainfall variability and high temperatures in Swaziland are the main characteristic of climate change, which has increased the frequency of drought, floods, wildfires, windstorms and hailstorms and consequently food insecurity and poverty. 


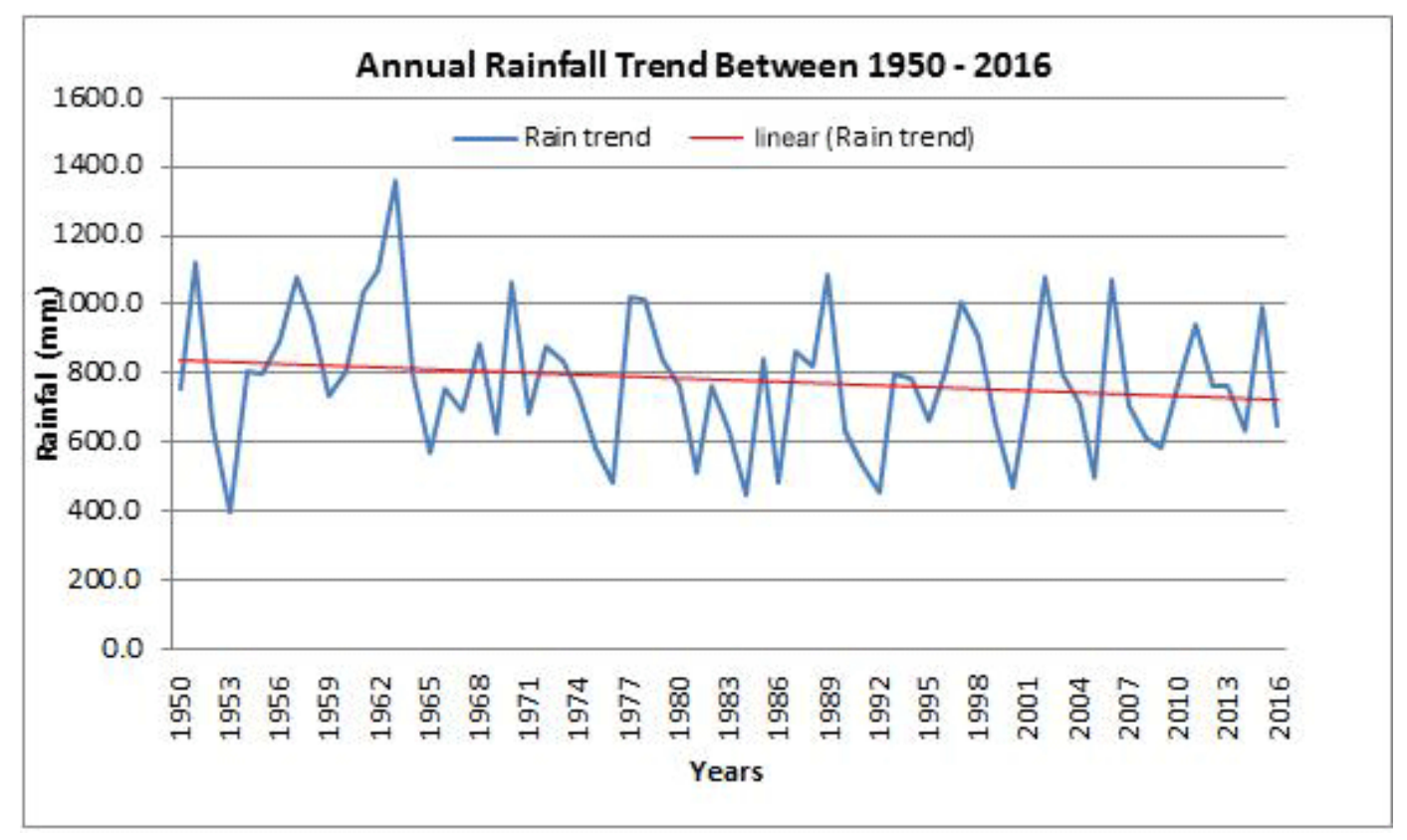

Figure 1. Annual Rainfall trend from 1950-2016

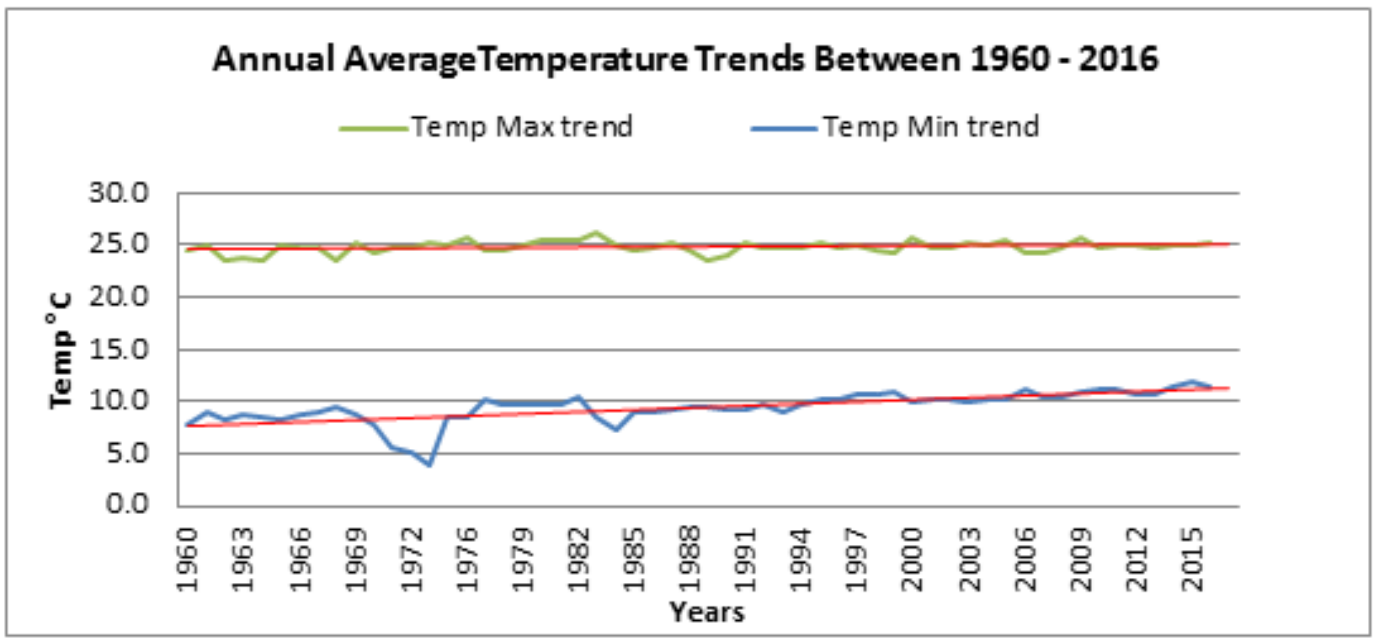

Source: Kenya Metrological Department Data, 2017

Figure 2. Mean annual rainfall trend of Narok from 1950 to 2016

The respondents also alleged to have witnessed climate change through observed reduction in the vegetation cover in the study area. In an interview with one of the key informants it was clear that some of the plant species that had become rare were partly due to heavy grazing and partly due to prolonged droughts and high temperatures that could not allow some species to regenerate after use. The plants mentioned include; Acacia geraldii ('osilalei'), Cotyledon Carribia ('Olmasilivi'), Castor Oil Bush ('Ondulei'), Candle Bush ('Oseneto'), Cabbage Tree ('Olrur'), Oxalis (enkasiesho) and Carissa edulis ('olamuriaki') and also diminished pasture growth over a long period and in most parts of the region leaving expansive bare grounds, (Plate 1). These sentiments had been reported by studies of other researchers who pointed out the combination of repeated droughts, rising temperature failed rainy seasons, hindering vegetation growth, and the disappearance of palatable pasture species leading to reduced availability of forage, leading to issues of overgrazing, and furthering the vulnerability of pastoralist production [32].

The findings of this study also indicated that majority $(32.8 \%)$ of the respondent were not aware of any trends in the flooding situations in the study area with only $21.9 \%$ indicating a decline in the trends of floods mainly from Narok East. This is possible because of declining rainfall amounts and that the pastoral livelihoods are more affected by impacts of prolonged droughts than those of floods. These findings are in agreement with reports by Ndamani and Watanabe [19] and Kusakari [20] where they found out that the farmers had perceived higher frequency and severity of drought than floods in Ghana due to decreasing 
rainfall trend.

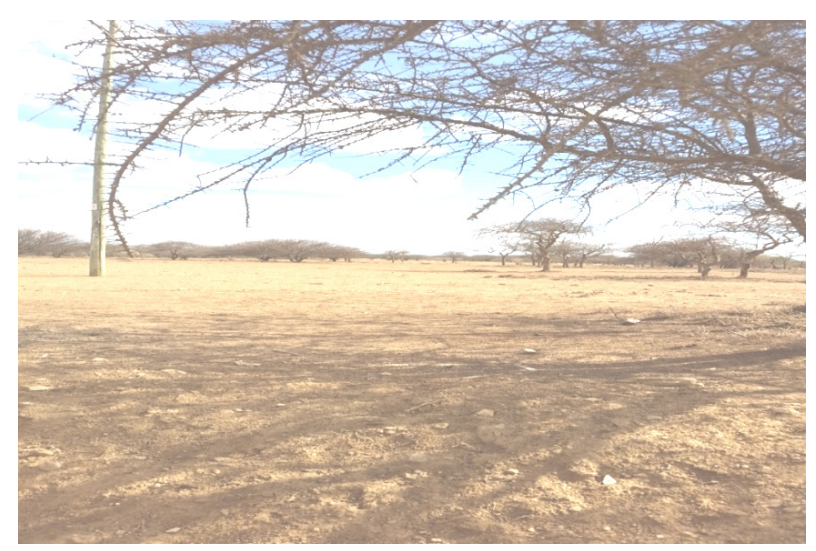

Plate 1. Vast land of overgrazed pastures in Narok South

However, for Okonya [33], farmers from Uganda perceived a higher rate of occurrence of flood than drought. In addition, a study by Ndukhu [34] showed that farmers in Kenya were aware of short-term climate changes, particularly an increase in temperatures, but their perception on these changes and the adaptations used varied across agro-climatic zones. Finally, Oremo [35] noted that farmers from Kitui County had perceived that conditions were getting drier and that rainfall trends were basically decreasing as time goes by.

\section{Conclusions}

This study demonstrates that the pastoral community was aware of the occurrence of climate change as observed from changes in the rainfall duration, amounts and subsequently drought cycles as well as the behavior of some vegetation species. However, their awareness was particularly based on using their own traditional knowledge and religious beliefs from which majority believed that the major cause of climate change is the offence of man to the gods a result of which man was being punished. While incorporation of indigenous knowledge to the climate change policies may be necessary to engage the community, such misguiding information is likely to hamper their adaptation strategies that could be based on the scientifically proven methodologies. The contacted respondents were asked whether they were aware of any change in climate related indicators such as temperature, vegetation cover, and rainfall over the past two decades. Although they were not able to clearly explain the causes of climate change, they were aware of the specific changes in climate indicators and were mainly informed by their own observation over time. The study also found out that information access in the study area especially that could help the pastoralists understand climate change better and perhaps adopt appropriate adaptation strategies was limited. Only a small number that received information from the local area chief or through their cell phones had managed to effectively and efficiently cope with impacts of climate change.

\section{Recommendation}

Based on the findings from this study, Maasai pastoralists depend on their locally available knowledge which is indigenous to observe and describe climatic changes other than scientifically proven facts communicated through print and media. There is need however to tap and incorporate such knowledge if appropriate into the climate change policy. Integration of this indigenous knowledge system can lead to effective adoption of adaptation strategies for safeguarding pastoral livelihoods.

Therefore, the government in collaboration with agricultural sector stakeholders, and mobile service providers should assist the pastoralists in ensuring the development of efficient and effective mobile phone-based agricultural information access systems that would relay the required information in real time for climate change preparedness. At the same time there is an urgent need to educate both the pastoralists and small scale farmers on both the causes and impacts of climate change before encouraging them to adapt to it because climate change is real.

\section{List of Abbreviations}

IPCC Intergovernmental Panel on Climate Change KCC WG Kenya Climate Change Working Group FAO Food and Agriculture Organization 


\section{Appendix: A Map of the Study Area (Narok County)}

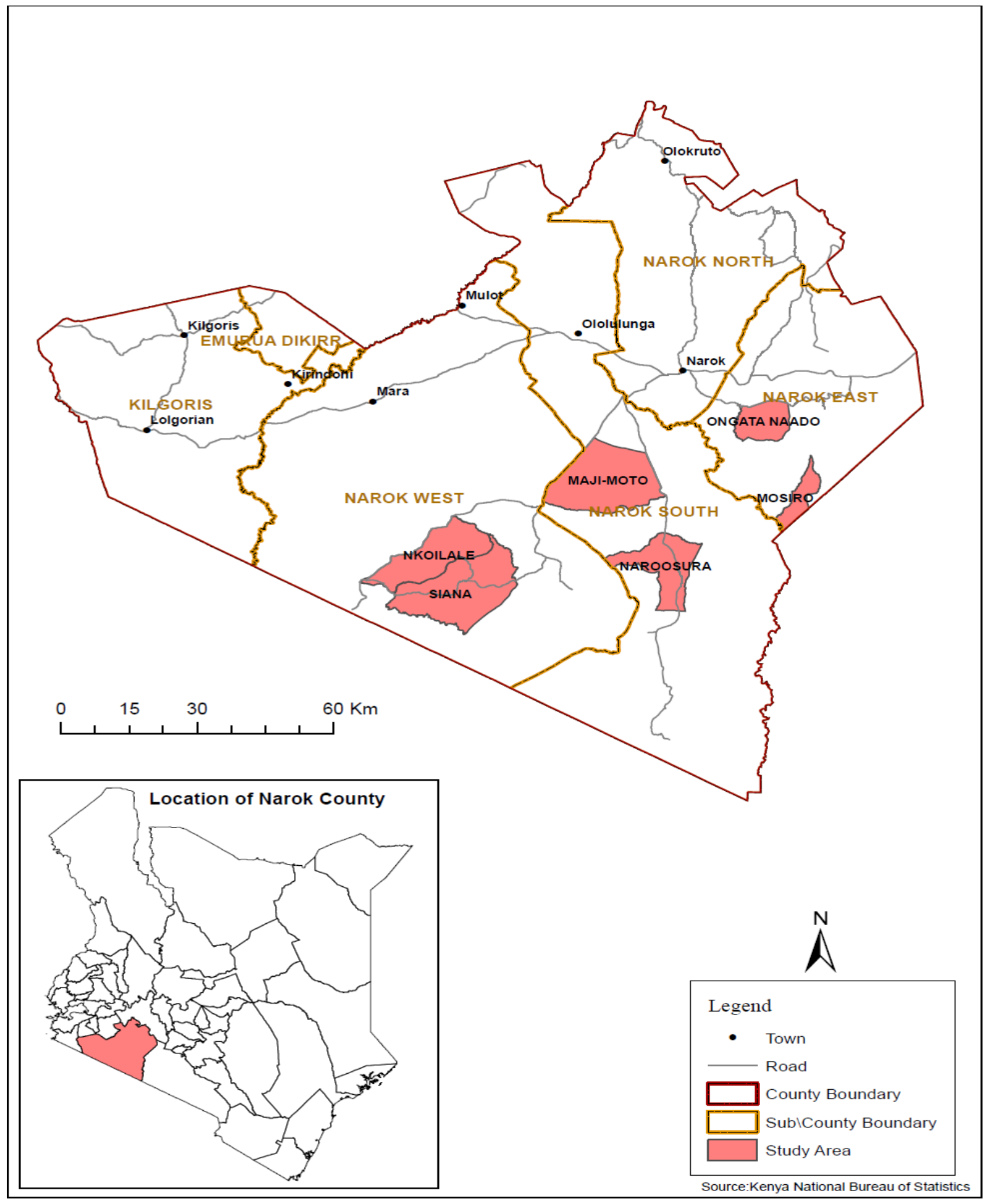

Source: KNBS 2016 


\section{REFERENCES}

[1] IPCC, (2018). Global Warming of 1.5: Summary for policy makers. Intergovernmental Panel on Climate Change. London: Cambridge University Press.

[2] Buchdahl, (1999).Climate Change Fact Sheet Series. Government Printers. Nairobi

[3] Wilbanks, T. J. \& Kates, R. W. (1999). Global change in local places: How scale matters. Climatic Change 43,601628.

[4] Bunce, M., Rosendo, S. \& Brown, K. (2010). Perceptions of climate change, multiple stressors and livelihoods on marginal African coasts, Environment, Development and Sustainability, 12,407-440.

[5] Thornton, P.K., \&Jones, P.G. (2008).Unpublished data layers. ILRI, Nairobi.

[6] Republic of Kenya, (2010). Agricultural Sector Development Strategy 2010-2020. Available at: http:// www.kilimo.go.ke/kilimo_docs/pdf/ASDS_Final.pdf (accessed on 2 September 2016).

[7] Nabutola, W. (2010). The Mau Forest in the Rift Valley: Kenya's Largest Water Tower: a Perfect Model for the Challenges and Opportunities of a Sustainable Development Project? FIG Congress 2010: Facing the Challenges - Building the Capacity Sydney, Australia, 11-16 April 2010

[8] FAO. (2010a). FAO Strategy for Forests and Forestry. Rome, Italy. (Also available at:http://www.fao.org/docrep/ 012/al043e/al043e00.pdf)

[9] Nkurumwa, A.O., Mwangi, J.G. \& Kathuri, N.J. (2010) Livelihood diversification and enhanced food security through agro-pastoralism: Socio-cultural and other challenges among Maasai pastoralists of Narok North district of Kenya. Second RUFORUM Biennial Meeting 20 - 24 September 2010, Entebbe, Uganda

[10] Gicheru, P., Makokha, S. N., Le, C., Gachimbi, L. N., Wamuongo, J. W., McNeil, D., \& Brouwer, F. (2012). Land subdivision and degradation in Narok, Kenya. Land Use Policies for Sustainable Development: Exploring Integrated Assessment Approaches, 148.

[11] Nesheim, I., Reidsma, P., Bezlepkina, I., Verburg, R., Abdeladhim, M. A., Bursztyn, M., Chen, L., Cisse, Y., Feng, S., Gicheru, P., Konig J. H., Novira, N., Purushothaman, S., Rodrigues-Filho, S., and Sghaier M., (2014). Causal chains, policy trade-offs and sustainability: Analysing land (mis) use in seven countries in the South. Land Use Policy, 37, 60-70.

[12] IPCC (2001).Climate change 2001: Impacts, adaptation, and vulnerability. Contribution of Working Group II to the Third Assessment Report of the Intergovernmental Panel on Climate Change. Cambridge, UK: Cambridge University Press.

[13] McMichael, A.J. (1996). Human population health. in Climate change 1995: impacts, adaptations, and mitigation of climate change: scientific-technical analyses. Contribution of Working Group II to the Second Assessment Report of the Intergovernmental Panel on Climate Change. Cambridge, UK: Cambridge University Press.

[14] Kamal, A., (2011).Vulnerability and adaptation strategies of rural people to climate change in Mid-Hills of Nepal. Tribhuvan University, Institute of Forestry. Pokhara, Nepal www.iof.edu.np

[15] Ogallo, L. (2010). The mainstreaming of climate change and variability information into planning and policy development for Africa. Procedia Environmental Sciences, 1, 405-410.

[16] KCCWG. (2013). Report on access and use of climate change information in the ASALs. KCCWG.

[17] Debela, N., Mohammed, C., Bridle, K., Corkrey, R., \& McNeil, D. (2015).Perception of climate change and its impact by smallholders in pastoral/agro pastoral systems of Borana, South Ethiopia. Springer Plus, 4(1), 236.

[18] Deressa, T. T., Hassan, R. M., \& Ringler, C. (2011).Perception of and adaptation to climate change by farmers in the Nile basin of Ethiopia. The Journal of Agricultural Science, 149(1), 23.

[19] Ndamani, F., \& Watanabe, T. (2015). Farmers' perceptions about adaptation practices to climate change and barriers to adaptation: A micro-level study in Ghana. Water, 7(9), 4593-4604.

[20] Kusakari, Y., Asubonteng, K. O., Jasaw, G. S., Dayour, F., Dzivenu, T., Lolig, V. ... \& Kranjac-Berisavljevic, G. (2014). Farmer-perceived effects of climate change on livelihoods in Wa West District, Upper West Region of Ghana. Journal of Disaster Research, 9(4).

[21] Omondi, L. A., \& Polk, M. A. O. M. (2015).Social Capital and Climate Change Perception in the Mara River Basin, Kenya.

[22] Egbe, C. A., Yaro, M. A., Okon, A. E., \&Bisong, F. E. (2014). Rural peoples' perception to climate variability/ change in cross river State-Nigeria. Journal of Sustainable Development, 7(2), 25.

[23] Nhemachena, C., \& Hassan, R. (2007). Micro-level analysis of farmers' adaption to climate change in Southern Africa. Intl Food Policy Res Inst.

[24] Yesuf, M., Falco, D. S., Deressa, T., Ringler, C., \& Kohlin, G., (2008). The Impact of Climate Change and Adaptation on Food Production in Low-Income Countries. Ethiopia Development Research Institute. International Food Policy Research Institute. Discussion Paper No: 828, Washington D.C. IFPRI

[25] GoK (2013). First County Integrated Development Plan 2013-2017. Kenya: County Government of Baringo.

[26] Mugenda, O. M., \& Mugenda, A. G. (2003).Research methods: Quantitative and qualitative approaches. Nairobi: Acts Press.

[27] Kenya National Bureau of Statistics (2015). Economic Survey 2015. Nairobi: Government Printer.

[28] Krejcie, R.V., \&Morgan D.W., (1970). Determining sample 
size for research activities. Educ. Psychol. Meas, 30(3), $607-610$

[29] Kothari, C. R. (2004). Research Methodology: Methods and Techniques, (Second Edition), New Age International Publishers.

[30] Oxley, M. (2011). Field note from Pakistan floods: Preventing future flood disasters. Jàmbá: Journal of Disaster Risk Studies, 3(2), 453-461.

[31] Manyatsi, A. M., Mhazo, N., \& Masarirambi, M. T. (2010).Climate Variability and Change as Perceived by Rural Communities in Swaziland. Research Journal of Environmental and Earth Sciences, 2(3), 165-170.

[32] Deressa, T. T., Hassan, R. M., Ringler, C., Alemu, T., \&Yesuf, M. (2009). Determinants of farmers' choice of adaptation methods to climate change in the Nile Basin of Ethiopia. Global environmental change, 19(2), 248-255.

[33] Okonya, J. S., Syndikus, K., \&Kroschel, J. (2013). Farmers' perception of and coping strategies to climate change: evidence from six Agro-ecological zones of Uganda. Journal of Agricultural Science, 5(8), 252.

[34] Ndukhu, H., Onwonga, R., Genga, Q., Wahome, G., \& Henning, J. (2014). Climate change and variability: Experiences, coping and adaptation strategies among the smallholder organic vegetable farmers in Central Kenya. In The 8th Egerton University International Conference Paper held on the 26th-28th March.

[35] Oremo, F. O. (2013). Small-scale farmers' perceptions and adaptation measures to climate change in Kitui County, Kenya (Doctoral dissertation), University of Nairobi, Nairobi. 